\title{
EFFICACY OF ENTOMOPATHOGENIC FUNGUS BEAUVERIA BASSIANA ISOLATES AGAINST THE TWO-SPOTTED SPIDER MITE, TETRANYCHUS URTICAE KOCH (ACARI: TETRANYCHIDAE)
}

\author{
YANAR, D.* - YANAR, Y. - BELGÜZAR, S. - ESER, İ. - KARAMEŞE ÜNALAN, H. \\ Department of Plant Protection, Tokat Gaziosmanpaşa University, Tokat, Turkey \\ (phone: +90-356-252-1616; fax: +90-356-252-1488) \\ *Corresponding author \\ e-mail: durdane.yanar@gop.edu.tr \\ (Received 12 $2^{\text {th }}$ Aug 2018; accepted $15^{\text {th }}$ Oct 2018)
}

\begin{abstract}
A total of 17 isolates of entomopathogenic fungus (Beauveria bassiana) were tested against adult females of the two-spotted spider mite (Tetranychus urticae Koch) under laboratory conditions. Spore suspension was prepared from 15 days old culture of the isolates on PDA medium. The fungal surface was scraped using a sterile loop with $10 \mathrm{ml}$ of sterile distilled water having $0.02 \%$ Tween 80 . Spore concentration of the filtrate was determined using a Neubauer Hemocytometer. This served as a stock suspension. In the pathogenicity tests $5 \times 10^{6}$ conidia $\mathrm{ml}^{-1}$ was used. Inoculation was performed by spaying spor suspension directly on the adult female mites. Inoculated mites were transferred on bean leaf disks in sterile petri dishes and incubated under room conditions at $25 \pm 2^{\circ} \mathrm{C}$ and $65 \pm 5 \% \mathrm{RH}$ for ten days. The mite sprayed with sterile distilled water having $0.02 \%$ Tween 80 were used as control. Mortality was noted daily. Dead mites were kept separately in humid sterile Petri dishes for another 10 days to determine the mycosis rate. Three isolates with higher mortality or mycosis rates (F-12, F-53, and F-56) were selected for dose-mortality tests. Spore suspension of the isolates at five different concentrations, $1 \times 10^{4}, 1 \times 10^{5}, 1 \times 10^{6}, 1 \times 10^{7}$, and $1 \times 10^{8}$ conidia ml $^{-1}$, was prepared and tested for its efficacy on adult females of two-spotted spidermite. The experiments were carried out with 3 replications and 10 adults were used for each replicate. In single dose trial, all isolates caused mortality to T. urticae adults. Different mortalities resulting from different isolates of $B$. bassiana were observed with the concentration of $5 \times 10^{6}$ conidia ml- ${ }^{-1}$ and varied from $32.5-72.5 \%$ at the end of $72 \mathrm{~h}$ incubation period. Mycosis ranged between 2.5\% and 40.0\%. In dose-mortality trial, isolate F53 caused the highest mortality percentage of T. urticae adults, followed by F-12 and F-56. The effectiveness of these isolates was not significantly different at the concentration of $1 \times 10^{8}$ conidia $\mathrm{ml}^{-1}$. Concentration of conidia affected the mortality of the mites differently $(\mathrm{P}<0.05)$. The results showed that mortality and mycosis were dose dependent which increased with enhancing the spore concentration of the isolates. Mortality ranged between $43.3 \%$ and $83 \%$ on isolate F-53 from $24 \mathrm{~h}$ to $72 \mathrm{~h}$ incubation period at concentration of $1 \times 10^{8}$ conidia ml ${ }^{-1}$. Followed by isolates F-12 and F-56 with $78.3 \%$ and $76.7 \%$ mortality rates, respectively. Maximum percent mycosis of $43.33 \%$ was recorded on $10^{\text {th }}$ day after treatment with the concentration of $1 \times 10^{8}$ conidia $\mathrm{ml}^{-1}$; in contrast to this minimum percent mortality of $3.33 \%$ was obtained by the application of the lowest concentration $1 \times 10^{4}$ conidia ml-1 at $\mathrm{F}-53$ isolate. The present results demonstrated that the entomopathogenic fungi isolates of $B$. bassiana could be used as an alternative for the control T. urticae.
\end{abstract}

Keywords: entomopathogen, Beauveria, biological control, mites

\section{Introduction}

In the world's agricultural areas one of the cosmopolitan pest is the two-spotted spider mite, Tetranychus urticae Koch. It causes the reduction of yield by sucking the plant cell sap and affect the plantgrowth and yield of infested plants (Meyer, 1996). Acaricides application is the common control practice of $T$. urticae so far. Indiscriminate use of acaricides not only has caused the environmental pollution but 
also created resistance to the pesticide in mites (Ay and Gurkan, 2005; Gerson and Weintraub, 2012). Therefore resistance development to the acaricides and the concerns about public health and environmental issues have impelled the researchers for alternative control measures. In this context, incorporation of entomopathogenic fungi as biocontrol agents in $T$. urticae management program is being explored. Entomopathogens as biocontrol agents have several advantages, comparing with synthetic acaricides such as, low cost, high efficacy, safe to environment and benificial organisms (Lacey et al., 2001). So, various researchers have tested different entomopathogenic fungi including Beauveria bassiana against Tetranychid mites in invitro and invivo trials (Shi and Feng, 2004; Chandler et al., 2005; Shi et al., 2008 Ujian and Shahzad, 2007; Anand and Tiwary, 2009). The aims of all these studies were to develop myco-acaricides for use in spider mites control programs. There are few microbial pesticides have been developed for the control of T. urticae (Faria and Wraight, 2007) although most isolates tested have been pathogenic to T. urticae and provided different levels of control on its population (Irigaray et al., 2003; Wekesa et al., 2006).

The biocontrol potential of entomopathogenic fungi usually vary among fungal species and isolates. Therefore, most virulent fungal isolates against specific mite species can be identified and manipulated. The present study were therefore, aimed to evaluate potential use of the local entomopathogenic $B$. bassiana isolates for controlling of the two- spotted spider mite (T. urticae) in in vitro conditions.

\section{Materials and methods}

\section{Two-spotted spider mite culture}

Two-spotted spider mites (Tetranychus urticae) were obtained from a colony of a continuous culture in the entomology Laboratory, Faculty of Agriculture, Department of Plant Protection, Tokat, Turkey. The initial culture originated from two-spotted spider mite collected from Tokat district, Turkey in 2013. The two-spotted spider mite population was reared and maintained on garden bean (Phaseolus vulgaris L.) at $25 \pm 2{ }^{\circ} \mathrm{C}$ and $65 \pm 5 \% \mathrm{RH}$, and 16:8 (L:D) photoperiod. To obtain fixed-age females for the bioassays, quiescent deutonymphs were collected from the two-spotted spider mite cultures and put on leaf discs. The newly emerged females were used for the experiments (Wekesa et al., 2006).

\section{Fungal isolates, culturing and preparation of conidial suspension}

Seventeen B. bassiana isolates were obtained from Tokat Gaziosmanpasa University, Department of Plant Protection culture collections. The virulence of isolates were tested on T. urticae female adults. The fungal isolates used in this study were obtained from soil in Kelkit Valley in Middle Black Sea Region, Turkey. Beauvaria bassiana isolates were identified morphologically and molecularly and used in previous studies (Yanar et al., 2014; Kepenekçi et al., 2017). Fungi were grown for 4 weeks at $25 \pm 2{ }^{\circ} \mathrm{C}$ on Sabouraud Dextrose Agar (SDA) (Difco) under natural light. Conidia were harvested by surface scraping 15-day-old culture plates. Subsequently the spore suspension was filtered through several layers of cheesecloth to remove mycelium. Inocula were suspended in 10-mL sterile distilled water containing $0.02 \%$ Tween 80 in $50 \mathrm{ml}$ falcon tube. The concentration of conidia in the sample suspensions was determined using a 
Neubauer Haemocytometer and adjusted to the final concentration required in the experiment by diluting the conidial suspension with $0.02 \%$ Tween 80 in water. Viability of conidia was determined before each bioassay by spread plating $0.1 \mathrm{~mL}$ of conidial suspension titrated at $5 \times 10^{6}$ conidia $\mathrm{mL}^{-1}$ on SDA plates. Sterile microscope cover slips were placed on each plate and plates were incubated at $26 \pm 2{ }^{\circ} \mathrm{C}$ and examined after $15-18 \mathrm{~h}$. Germination percentage was determined from 100 spore counts at $40 \times$ magnification.

\section{Single-dose screening bioassay}

Total of 17 Beauveria bassiana isolates were screened against Tetranychus urticae under laboratory conditions. Conidial suspension $(300 \mu \mathrm{l})$ of each isolate $\left(5 \times 10^{6}\right.$ conidia $/ \mathrm{ml}$ ) with $0.02 \%$ Tween 80 solution were sprayed directly on 10 adult mites in $1.5 \mathrm{ml}$ plastic cage by using a hand sprayer. One day after sprayed inoculation, the mites were transferred on $25 \mathrm{~mm}$ diameter bean leaf disc placed on moist cotton in the $90 \mathrm{~mm}$ in diameter glass petri dish using a single hair brush. The petri dishes were placed in an incubator at $25 \pm 2{ }^{\circ} \mathrm{C}, 65 \pm 5 \% \mathrm{RH}$, and 16:8 (L:D) photoperiod. Each treatment was replicated 3 times. The experiments were repeated two times. Control was sprayed with $300 \mu \mathrm{l}$ of sterile distilled water containing $0.02 \%$ Tween 80 . Twospotted spider mites were checked daily for mortality, and all cadavers were placed at $>90 \%$ relative humidity in an incubator at $25 \pm 2{ }^{\circ} \mathrm{C}, 65 \pm 5 \% \mathrm{RH}$ until condition was observed. Mycosis was confirmed by microscopic examination of the hyphae and spores on the surface of the cadavers.

\section{Dose-mortality bioassays}

Three isolates exhibited intense sporulation, higher mortality or mycosis rates in single dose bioassays were used in this test. Conidia of these isolates were prepared as mentioned above and the conidia viability was also assessed before application. Five different concentrations $\left(1 \times 10^{4}, 1 \times 10^{5}, 1 \times 10^{6}, 1 \times 10^{7}, 1 \times 10^{8}\right.$ conidia $\left.\mathrm{ml}^{-1}\right)$ of conidial suspension in $0.02 \%$ Tween 80 solution were prepared for each isolates and sprayed on the mites as mentioned above and $0.02 \%$ Tween 80 solution was used as a negative control. All the experimental procedure remained the same as described earlier.

\section{Data analysis}

Data were corrected for mortality in the control using Abbott's Formula (Abbott, 1925). The percent mortality of each fungus was subjected to ANOVA test and the means were compared by the Tukey's test, using SPSS 17.0 software program (SPSS, 2008). Dose mortality data was analyzed using POLO_PC (Leora, 1994) probit and logit analysis software according to Finney (1971). All calculations of half maximal lethal concentration $\left(\mathrm{LC}_{50}\right)$ values, lethal concentration ratios and the tests of the equality and parallelism of slopes were carried out with POLO-PC program.

\section{Results}

In sigle dose trial, among the $17 \mathrm{~B}$. bassiana isolates tested, few of them were highly pathogenic to $T$. urticae adults, but the mortalities of mites caused by most of them were significantly higher than that of the negative control at the end of $72 \mathrm{~h}$ post-inoculation $(\mathrm{P}<0.05)$. The mortality level of the control in this study was low which indicated that 
the mortality due to fungal infection. The maximum mortality in the control was $6.7 \%$ at the end of $72 \mathrm{~h}$ incubation period. All of the isolates were pathogenic to T. urticae. After $72 \mathrm{~h}$, percentage mortality at $5 \times 10^{6}$ conidia $\mathrm{ml}^{-1}$ varied from $32.5 \%$ to $72.5 \%$ (Table 1). Isolate F-56 showed the highest mortality $(72.5 \pm 4.79 \%)$, followed by the isolates F-53 $(70.0 \pm 5.77 \%)$ and F-12 $(68.8 \pm 4.34 \%)$ at the dose of $5 \times 10^{6}$ conidia $\mathrm{mL}^{-1}$ (Table 1).

Table 1. Efficacy of entomopathogenic fungal isolates $\left(5 \times 10^{6}\right.$ conidia $\left.\mathrm{mL}^{-1}\right)$ on Tetranychus urticae

\begin{tabular}{c|c|c|c}
\hline \multirow{2}{*}{ Treatments } & $\mathbf{2 4} \mathbf{h}$ & $\mathbf{4 8 ~ h}$ & $\mathbf{7 2 ~ h}$ \\
\cline { 2 - 4 } & \multicolumn{3}{|c}{ Mortality \% } \\
\hline Control & $6.7 \pm 1.67 * \mathrm{a}$ & $6.7 \pm 3.33 \mathrm{a}$ & $6.7 \pm 3.89 \mathrm{a}$ \\
F-2 & $27.5 \pm 2.50 \mathrm{~b}$ & $28.8 \pm 2.26 \mathrm{~b}$ & $32.5 \pm 5.59 \mathrm{~b}$ \\
F-4 & $34.3 \pm 5.71 \mathrm{~b}$ & $40.0 \pm 8.73 \mathrm{bc}$ & $50.0 \pm 6.55 \mathrm{bc}$ \\
F-7 & $32.9 \pm 4.74 \mathrm{~b}$ & $34.3 \pm 4.28 \mathrm{~b}$ & $58.6 \pm 7.38 \mathrm{bc}$ \\
F-12 & $55.6 \pm 7.09 \mathrm{c}$ & $60.0 \pm 6.01 \mathrm{c}$ & $68.8 \pm 4.34 \mathrm{~d}$ \\
F-15 & $28.8 \pm 3.98 \mathrm{~b}$ & $47.5 \pm 4.53 \mathrm{bc}$ & $61.3 \pm 6.10 \mathrm{c}$ \\
F-42 & $32.5 \pm 3.13 \mathrm{~b}$ & $42.5 \pm 7.26 \mathrm{bc}$ & $57.5 \pm 8.40 \mathrm{bc}$ \\
F-53 & $40.0 \pm 3.33 \mathrm{bc}$ & $53.3 \pm 8.82 \mathrm{bc}$ & $70.0 \pm 5.77 \mathrm{~d}$ \\
F-56 & $44.0 \pm 4.27 \mathrm{bc}$ & $49.0 \pm 7.37 \mathrm{bc}$ & $72.5 \pm 4.79 \mathrm{~d}$ \\
F-73 & $22.5 \pm 2.50 \mathrm{~b}$ & $55.0 \pm 9.57 \mathrm{bc}$ & $63.0 \pm 5.17 \mathrm{c}$ \\
F-76 & $26.7 \pm 6.67 \mathrm{~b}$ & $46.7 \pm 8.82 \mathrm{bc}$ & $50 \cdot 0 \pm 5.78 \mathrm{bc}$ \\
F-97 & $32.5 \pm 4.79 \mathrm{~b}$ & $47.5 \pm 8.54 \mathrm{bc}$ & $62.5 \pm 4.79 \mathrm{c}$ \\
F-108 & $30.0 \pm 2.67 \mathrm{~b}$ & $37.5 \pm 3.66 \mathrm{bc}$ & $61.3 \pm 6.39 \mathrm{c}$ \\
F-123 & $26.7 \pm 2.11 \mathrm{~b}$ & $35.0 \pm 3.41 \mathrm{ab}$ & $43.3 \pm 6.15 \mathrm{~b}$ \\
F-127 & $46.7 \pm 3.33 \mathrm{bc}$ & $60 \pm 5.77 \mathrm{bc}$ & $56.7 \pm 3.33 \mathrm{bc}$ \\
F-145 & $28.9 \pm 3.51 \mathrm{~b}$ & $43.33 \pm 5.53 \mathrm{bc}$ & $64.4 \pm 4.44 \mathrm{c}$ \\
F-156 & $36.7 \pm 3.33 \mathrm{~b}$ & $56.7 \pm 8.82 \mathrm{bc}$ & $57.3 \pm 8.82 \mathrm{bc}$ \\
F-159 & $45.6 \pm 5.30 \mathrm{bc}$ & $47.4 \pm 4.75 \mathrm{bc}$ & $55.4 \pm 7.66 \mathrm{~b}$ \\
\hline
\end{tabular}

${ }^{*}$ The data are presented as the mean \pm SE. The same letters in the same column represent no significant differences between the groups at the $P<0.05$ level by Tukey's HSDTest

The percentages of mycosed mite were $40 \%$ for isolate F-73, $11.25 \%$ for isolate F56 , and $5 \%$ for isolate F-53 and F-12 at $5 \times 10^{6}$ conidia concentration $\mathrm{ml}^{-1}$ single dose treatment (Fig. 1).

Dose response studies were conducted with effective isolates F-53, F-56 and F-12. In dose studies with F-53, F-56 and F-12 mortality percentages of T. urticae adult at $72 \mathrm{~h}$ post-inoculation varied between the different concentrations within the isolates $(\mathrm{P}<0.05)$. Almost similar mortalities resulting from different isolates of $B$. bassiana were observed with the dose of $1 \times 10^{7}$ conidia $\mathrm{mL}^{-1}$ (Tables 2, 3 and 4). Isolate F-53 obviously caused the highest mortality of $T$. urticae, followed by isolate F-12 at the end of $72 \mathrm{~h}$ incubation with the dose of $1 \times 10^{8}$ conidia $\mathrm{mL}^{-1}$ (Tables 2 and 4 ). However, the effectiveness of isolates F-53, F-12 and F-56 were not significantly different at a dose of $1 \times 10^{8}$ conidia ml-1. Also, mortalities of $T$. urticae adults resulting from the two highest doses $\left(1 \times 10^{7}\right.$ and $1 \times 10^{8}$ conidia mL-1) for each of the isolates, were significantly 
different $(\mathrm{P}<0.05)$ (Tables 2, 3 and 4). The mortality of control was significantly less than the each dose of the isolates tested $(\mathrm{P}<0.05)$ (Tables 2 and 3$)$.

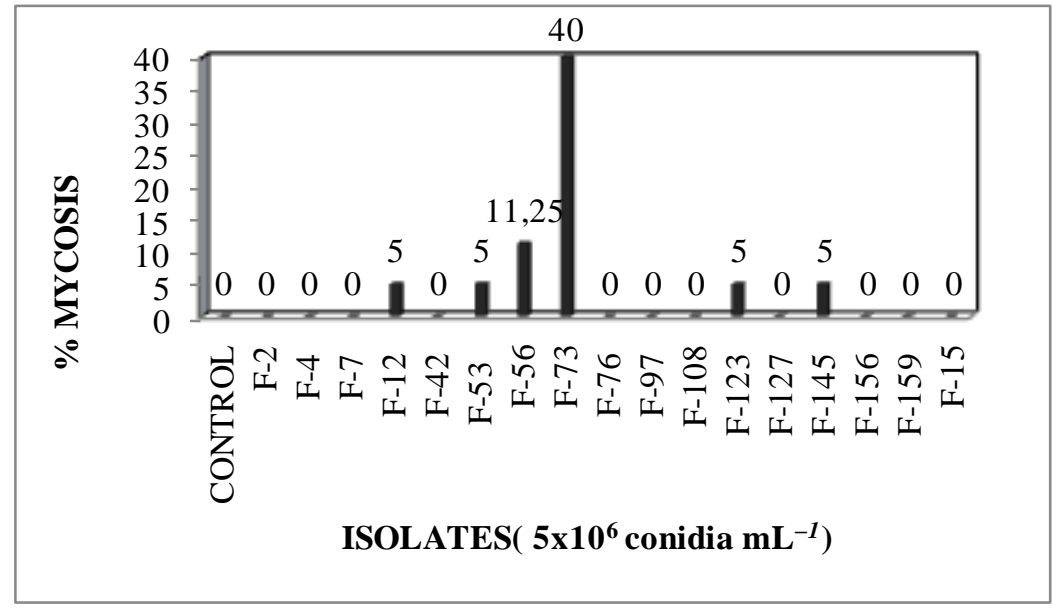

Figure 1. Mycosis rates of entomopathogenic fungal isolates $\left(5 \times 10^{6}\right.$ conidia $\left.\mathrm{mL}^{-1}\right)$ on Tetranychus urticae

Table 2. Efficacy of F-53, F-56 and F-12 entomopathogenic fungal isolates dose treatment on Tetranychus urticae

\begin{tabular}{|c|c|c|c|}
\hline \multirow{2}{*}{ Treatments } & $24 \mathrm{~h}$ & $48 \mathrm{~h}$ & $72 \mathrm{~h}$ \\
\hline & \multicolumn{3}{|c|}{ Mortality \% } \\
\hline Control & $6.67 \pm 3.33 * a$ & $6.67 \pm 3.33 \mathrm{a}$ & $6.67 \pm 3.33 \mathrm{a}$ \\
\hline F-53 0.01X10 & $23.33 \pm 3.33 \mathrm{abc}$ & $30.00 \pm 5.77 \mathrm{bcde}$ & $30.00 \pm 5.77 b c$ \\
\hline F-53 0.1X10 & $23.33 \pm 3.33 \mathrm{abc}$ & $33.33 \pm 3.33 \mathrm{bcde}$ & $33.33 \pm 3.33 \mathrm{bcd}$ \\
\hline F-53 $1 \times 10^{6}$ & $23.33 \pm 3.33 \mathrm{abc}$ & $26.67 \pm 3.33 \mathrm{abcd}$ & $33.33 \pm 3.33 \mathrm{bcd}$ \\
\hline F-53 $1 \times 10^{7}$ & $43.33 \pm 3.33 \mathrm{~d}$ & $50.00 \pm 0.00 \mathrm{e}$ & $53.33 \pm 3.33 \mathrm{~d}$ \\
\hline F-53 $1 \times 10^{8}$ & $43.33 \pm 3.33 \mathrm{~d}$ & $50.00 \pm 0.00 \mathrm{e}$ & $53.33 \pm 3.33 d$ \\
\hline F-56 0.01X $10^{6}$ & $16.67 \pm 3.33 \mathrm{ab}$ & $20.00 \pm 0.00 \mathrm{abc}$ & $30.00 \pm 0.00 \mathrm{bc}$ \\
\hline F-56 0.1X10 & $23.33 \pm 3.33 \mathrm{abc}$ & $23.33 \pm 3.33 \mathrm{abc}$ & $30.00 \pm 0.00 \mathrm{bc}$ \\
\hline F-56 $1 \times 10^{6}$ & $33.33 \pm 3.33 b c$ & $36.67 \pm 6.67 \mathrm{bcde}$ & $43.33 \pm 3.33 \mathrm{~cd}$ \\
\hline F-56 $1 \times 10^{7}$ & $36.67 \pm 3.33 \mathrm{~cd}$ & $40.00 \pm 5.77 \mathrm{cde}$ & $43.33 \pm 3.33 \mathrm{~cd}$ \\
\hline F-56 $1 \times 10^{8}$ & $36.67 \pm 3.33 \mathrm{~cd}$ & $46.67 \pm 3.33 \mathrm{de}$ & $46.67 \pm 3.33 \mathrm{~cd}$ \\
\hline F-12 0.01X10 & $16.67 \pm 3.33 \mathrm{ab}$ & $16.67 \pm 3.33 \mathrm{ab}$ & $16.67 \pm 3.33 \mathrm{ab}$ \\
\hline F-12 $0.1 \times 10^{6}$ & $16.67 \pm 3.33 \mathrm{ab}$ & $26.67 \pm 3.33 \mathrm{abcd}$ & $30.00 \pm 5.77 b c$ \\
\hline F-12 $1 \times 10^{6}$ & $26.67 \pm 3.33 \mathrm{bcd}$ & $33.33 \pm 6.67 \mathrm{bcde}$ & $43.33 \pm 6.67 \mathrm{~cd}$ \\
\hline F-12 $1 \times 10^{7}$ & $26.67 \pm 3.33 \mathrm{bcd}$ & $33.33 \pm 6.67 \mathrm{bcde}$ & $43.33 \pm 6.67 \mathrm{~cd}$ \\
\hline F-12 $1 \times 10^{8}$ & $30.00 \pm 0.00 \mathrm{bcd}$ & $36.67 \pm 3.33 \mathrm{bcde}$ & $43.33 \pm 3.33 \mathrm{~cd}$ \\
\hline
\end{tabular}

${ }^{*}$ The data are presented as the mean \pm SE. The same letters in the same column represent no significant differences between the groups at the $P<0.05$ level by Tukey's HSDTest

The percentage of mycosed mite was between 3.33 and $43.33 \%$ for isolate F-53. It was between 8.33 and $40 \%$ for isolate F-56, and between 5 and $23.33 \%$ for isolate F-12. 
For all the isolates tested, mycosis rates were higher at $1 \times 10^{8}$ conidia concentration $\mathrm{mL}^{-1}$ (Table 3).

Table 3. Mycosis rates of F-53, F-56 and F-12 entomopathogenic fungal isolates different doses on Tetranychus urticae

\begin{tabular}{|c|c|c|c|c|c|}
\hline \multirow{3}{*}{ Treatments } & \multicolumn{5}{|c|}{ Dozlar conidia $\mathrm{mL}^{-1}$} \\
\hline & $0.01 \times 10^{6}$ & $0.1 \times 10^{6}$ & $1 \times 10^{6}$ & $1 \times 10^{7}$ & $1 \times 10^{8}$ \\
\hline & \multicolumn{5}{|c|}{ Mycosis \% } \\
\hline F-12 & $5 * a$ & $15 b$ & $18.33 b$ & $18.33 \mathrm{a}$ & $23.33 \mathrm{a}$ \\
\hline F-53 & $3.33 \mathrm{a}$ & $10 \mathrm{a}$ & $10 \mathrm{a}$ & $40 \mathrm{c}$ & $43.33 b$ \\
\hline F-56 & $16.67 \mathrm{~b}$ & $16.67 b$ & $16.67 \mathrm{~b}$ & $30 \mathrm{~b}$ & $40 \mathrm{~b}$ \\
\hline
\end{tabular}

The same letters in the same column represent no significant differences between the groups at the $\mathrm{P}<0.05$ level by Tukey's HSDTest

For $72 \mathrm{~h}$ mortality rates were evaluated for $\mathrm{LC}_{50}$ values with POLO PC program. Results showed that $\mathrm{LC}_{50}$ values of F-12, F-53 and F-56 were $9.12 \times 10^{7}, 6.6 \times 10^{7}$ and $4.3 \times 10^{7}$ respectively. $\mathrm{LC}_{50}$ values fiducial limits (95\%) of F-12, F-53 and F-56 were2.49-42.16, 1.89-27.65 and 1.4-9.25 respectively (Table 4).

Table 4. $L C_{50}$ values and fiducial limits of different ontomopatogenic Beauvaria bassiana isolates for two-spotted spider mite at the end of $72 \mathrm{~h}$

\begin{tabular}{c|c|c|c|c}
\hline Beauvaria bassiana isolates & LC $_{\mathbf{5 0}}$ values & Fiducial limits for $\mathbf{L C}_{\mathbf{5 0}}$ & Slope \pm SE & Chi-square \\
\hline F-12 & $9.12 \times 10^{7}$ & $2.49-42.16$ & $0.49 \pm 0.04$ & 211.36 \\
F-53 & $6.6 \times 10^{7}$ & $1.89-27.65$ & $0.36 \pm 0.04$ & 124.61 \\
F-56 & $4.3 \times 10^{7}$ & $1.4-9.25$ & $0.37 \pm 0.04$ & 127.38 \\
\hline
\end{tabular}

\section{Discussion}

Control programmes of spider mites are aimed at maintaining the Tetranychus spp. population at low levels throughout the growing season. Therefore, the main target in integrated spider mite management could be the adult female mites. The studies indicated that the acaricidal activities of most of the entomopathogenic fungi towards $T$. urticae can be attributed to disruption of mite development through their penetration and subsequent nutrient uptake (Zhang et al., 2014; Shi and Feng, 2009). The results were presented and discussed below in the light of earlier studies. In single dose trial, all the tested $B$. bassiana isolates pathogenic to $T$. urticae adults and the mortalities of mites caused by them were significantly higher than that of the negative control at the end of $72 \mathrm{~h}$ post-inoculation $(\mathrm{P}<0.05)$. The mortality rate of the control was low $(6.67 \%)$ at the end of $72 \mathrm{~h}$ incubation period which indicated that the mortality due to fungal infection. The percentage mortality at $5 \times 10^{6}$ conidia $\mathrm{mL}^{-1}$ varied from $32.5 \%$ to $72.5 \%$ after $72 \mathrm{~h}$. Isolate F-56 showed the highest mortality $(72.5 \pm 4.79 \%)$, followed by the isolates F-53 $(70.0 \pm 5.77 \%)$ and F-12 $(68.8 \pm 4.34 \%)$ at the dose of $5 \times 10^{6}$ conidia $\mathrm{ml}^{-1}$ (Table 1). Also, sporulations of these isolates were higher on PDA media at the end of 10 days incubation period. The results obtained in the present study have similarity with those of other scientists that used entomopathogen fungi against mites (Wekesa, et al., 2006; Fayyadh et al., 2005; Slavimira and Simova, 2010; Gatarayiha et al., 2012). 
Gatarayiha et al. (2012) reported that mortality caused by $62 \mathrm{~B}$. bassiana isolates on $T$. urticae adults ranged between 0.5 and $92.8 \%$; and 23 isolates resulted in more than $\% 50$ mortality. The variation in virulence among the different fungal isolates to T. urticae may be associated with the enzymes produced by each isolate. De La Rosa et al. (1997) suggested that the differences in virulence of entomopathogenic fungal isolates are probably associated with the presence of enzymes that influence the penetration process of the fungus. Secondary metabolites produced by entomopathogen fungi for example, toxins such as beauvericin, present in $B$. bassiana, which vary in could also contribute to the observed variation in virulence (Roberts and St. Leger, 2004). At $5 \times 10^{6}$ conidia concentration $\mathrm{mL}^{-1}$ single dose treatment, the mycosis rates were $40,11.25,5$, and $5 \%$ for isolates F-70, F-56, F53, and F-12, respectively (Fig. 1).

Dose response studies were made with effective isolates F-53, F-56 and F-12. Isolate F-53 obviously caused the highest mortality of T. urticae, followed by isolate F-12 at the end of $72 \mathrm{~h}$ incubation with the dose of $1 \times 10^{8}$ conidia $\mathrm{mL}^{-1}$ (Tables 2 and 4). However, the effectiveness of isolates F53, F-12 and F-56 were not significantly different at a dose of $1 \times 10^{8}$ conidia ml-1. Also, mortalities of T. urticae adults resulting from the two highest doses $\left(1 \times 10^{7}\right.$ and $1 \times 10^{8}$ conidia $\left.\mathrm{mL}^{-1}\right)$ for each of the isolates, were significantly different $(\mathrm{P}<0.05)$ (Tables 2,3 and 4$)$. The mortality of control was significantly less than the each dose of the isolates tested ( $<<0.05$; Tables 2 and 3). The results observed in present study are in accordance with Gatarayiha et al. (2012) in which different strains of $B$. bassiana were used against $T$. urticae adults at different concentrations. The highest concentration $\left(1 \times 10^{8}\right.$ spores $\left.\mathrm{mL}^{-1}\right)$ showed the maximum mortality percentage on $T$. urticae. Similarly, Oliveira et al. (2002) worked with $B$. bassiana isolates at $1 \times 10^{8}$ conidia $\mathrm{ml}-1$ and the red mite Oligonychus yothersi, recorded $77.00 \%$ to $98.00 \%$ mortality. All tested fungi proved to be pathogenic to $T$. urticae adults. A similar level of control by B. bassiana isolates against tetranychid mites in laboratory trials was observed by Barreto et al. (2004) and Wekesa et al. (2006).

Results showed that $\mathrm{LC}_{50}$ values of F-12, F-53 and F-56 were $9.12 \times 10^{7}, 6.6 \times 10^{7}$ and $4.3 \times 10^{7}$ respectively. $\mathrm{LC}_{50}$ values fiducial limits $(95 \%)$ of F-12, F-53 and F-56 were 2.49-42.16, 1.89-27.65 and 1.4-9.25 respectively (Table 4). Furthermore, the dosemortality studies suggested that B. bassiana isolate F-56 is efficient in controlling the adult mites as having the lowest LC50 $\left(4.3 \times 10^{7}\right.$ conidia/ $\left.\mathrm{mL}^{-1}\right)$ value showing the most virulent isolate among all tested isolates. These results are in conformity with those of Shi and Feng (2009) who used B. bassiana, P. fumosoroseus and M. anisopliae isolates and got $73.1,75.4$ and $67.9 \%$ mortality of mites after 10 days of spraying.

\section{Conclusion}

In conclusion, the two-spotted spider mite (T. urticae) was found to be susceptible to the isolates F-12, F-53 and F-56 of the entomopathogenic fungus B. bassiana at two higher doses $\left(1 \times 10^{7}\right.$ and $1 \times 10^{8}$ conidia $\left.\mathrm{mL}^{-1}\right)$. Further studies will be conducted to determine the efficacy of these isolates under greenhouse conditions.

Conflict of interests. The authors declare no conflict of interests. 


\section{REFERENCES}

[1] Abbott, W. S. (1925): A method of computing the effectiveness of an insecticide. - J. Econ. Entomol. 18: 265-267.

[2] Anand, R., Tiwary, B. N. (2009): Pathogenicity of entomopathogenic fungi to eggs and larvae of Spodoptera litura, the common cutworm. - Biocontrol Sci Technol 19(9): 919929.

[3] Ay, R., Gürkan, M. O. (2005): Resistance to bifenthrin and resistance mechanisms of different strains of the two-spotted spider mite (Tetranychus urticae Koch) from Turkey. - Phytoparasitica 33(3): 237-244.

[4] Barreto, R. S., Marques, E. J., Gondim, Jr. M. G., de Oliveira, J. V. (2004): Selection of Beauveria bassiana (Bals.) Vuill. and Metarhizium anisopliae (Metsch.) Sorok. for the control of the mite Mononychellus tanajoa (Bondar). - Sci. Agric. 61: 659-664.

[5] Chandler, D., Davidson, G., Jacobson, R. J. (2005): Laboratory and glasshouse evaluation of entomopathogenic fungi against the two spotted spider mite, Tetranychus urticae (Acari: Tetranychidae), on tomato, Lycopersicon esculentum. - Biocontrol Sci Technol 15: 37-54.

[6] De La Rosa, W., Alatorre, R., Truj1llo, J., Barrera, J. F. (1997): Virulence of Beauveria bassiana (Deuteromycetes) strains against the coffee borer (Coleoptera: Scolytidae). - J Econ Entomol 90: 1534-1538.

[7] Faria, M., Wraight, S. P. (2007): Mycoinsecticides and mycoacaricides: A comprehensive list with worldwide coverage and international classification of formulation types. - Biol Control 43: 237-256.

[8] Fayyadh, M. A., Jabar, S., Radi, M. H. (2005): Biological control of two spotted spider mite Tetranychus urticae by tow isolate of B. bassiana. - Basra J Agric Sci 20: 70-74.

[9] Finney, D. J. (1971): Probit Analysis. 3rd edn. - Cambridge University Press, London.

[10] Gatarayiha, M. C., Laing, M. D., Miller, R. M. (2012): Selection of Beauveria bassiana strains against the two spotted spider mite, Tetranychus urticae Koch in laboratory and greenhouse trials. - African J Microbiol Res 6(11): 2694-2703.

[11] Gerson, U., Weintraub, P. G. (2012): Mites (Acari) as factor in greenhouse management. - Annu Rev Entomol 57;229-247.

[12] Irigaray, F. J., Marco-Mancebon, V., Perez-Moreno, I. (2003): The entomopathogenic fungus Beauveria bassiana and its compatibility with triflumuron: effects on the twospotted spider mite Tetranychus urticae. - Biological Control 26: 168-173.

[13] Kepenekçi, İ., Sağlam, H. D., Oksal, E., Yanar, D., Yanar, Y. (2017): Nematicidal activity of Beauveria bassiana (Bals.-Criv.) Vuill. against roots-knot nematode in tomato grown under natural conditions. - Egyptian Journal of Biological Pest Control 27(1): 117-120.

[14] Lacey, L. A., Frutos, R., Kaya, H. K., Vail, P. (2001): Insect pathogens as biocontrol agents: do they have a future? - Biol Control 21: 230-248.

[15] Leora, S. (1994): Polo-PC: Probit and Logit Analysis. - LeOra Software, Berkeley, CA.

[16] Meyer, M. K. (1996): Mite Pests and Their Predators on Cultivated Plants in Southern Africa. Vegetables and Berries. - ARC, South Africa.

[17] Oliveira, R. C., Alves, L. F., Neves, P. M. (2002): Suscetibilidade de Oligonychus yothersi (Acari: Tetranychidae) ao fungo Beauveria bassiana. - Scientia Agricola 59(1): 187-189.

[18] Roberts, D. W., St Leger, R. J. (2004): Metarhizium spp., cosmopolitan insect-pathogenic fungi: mycological aspects. - Advances in Applied Microbiology 54: 1-70.

[19] Shi, W. B., Feng, M. G. (2004): Lethal effect of Beauveria bassiana, Metarhizium anisopliae, and Paecilomyces fumosoroseus on the eggs of Tetranychus urticae (Acari: Tetranychidae) with a description of a mite egg bioassay system. - Biol Control 30: 165173. 
[20] Shi, W. B., Feng, M. G. (2009): Effect of fungal infection on reproductive potential and survival time of Tetranychus urticae (Acari: Tetranychidae). - Exp Appl Acarol 48: 229237.

[21] Shi, W. B., Zhang, L., Feng, M. G. (2008): Time concentration - mortality responses of carmine spider mite (Acari: Tetranychidae) females to three hypocrealean fungi as biocontrol agents. - Biol Control 46: 495-501.

[22] Slavimira, A. D., Simova, S. A. (2010): Susceptibility of Tetranychus urticae Koch. (Acari: Tetranychidae) to isolates of entomopathogenic fungus Beauveria bassiana. Pestic Phytomed 25(1) 51-57.

[23] SPSS (2008): SPSS Statistics for Windows, Version 17.0. - SPSS Inc, Chicago IL, USA.

[24] Ujian, A. A., Shahzad, S. (2007): Pathogenicity of Metarhizium anisopliae var. acridum strains on pink hibiscus mealy bug (Maconellicoccus hirsutus) affecting cotton crop. Pakistan J Bot 39(3): 967-973.

[25] Wekesa, V. W., Knapp, M., Maniania, N. K., Boga, H. I. (2006): Effects of Beauveria bassiana and Metarhizium anisopliae on mortality, fecundity and egg fertility of Tetranychus evansi. - J Appl Entomol 130: 155-159.

[26] Yanar, Y., Yanar, D., Belgüzar, S., Soy, B., İğneli, M., B. Özbek, B. (2014): Evaluation of entomopathogenic fungal isolates against the rose aphid, Macrosiphum rosae L. (Hemiptera: Aphididae). - International Conference on Biopesticides 19-25 Ekim 2014, Antalya, Turkey.

[27] Zhang, L., Shi, W. B., Feng, M. G. (2014): Histopathological and molecular insights into the ovicidal activities of two entomopathogenic fungi against two-spotted spider mite. $-\mathbf{J}$ Intervebr Pathol 117: 73-78. 